\title{
ANALISIS PROBLEMATIKA PERPUSTAKAAN PERGURUAN TINGGI ISLAM DI INDONESIA MENGHADAPI ERA 4.0
}

\author{
Rhoni Rodin \\ Institut Agama Islam Negeri (IAIN) Curup. \\ rhoni.rodin@iaincurup.ac.id
}

\begin{abstract}
The era of 4.0 is the era of technological industrial revolution which will fundamentally change the paradigm of thinking and how to work. This paper aims to analyze what are the problems faced by Islamic higher education libraries in welcoming the era of 4.0. This type of research is a literature study. Literature studies can be obtained from various sources, journals, books, documentation, internet and literature. while analyzing data with descriptive analysis method. The results show that there are several problems faced by Islamic tertiary education libraries in Indonesia, namely that Islamic university libraries not only prioritize traditional roles by providing physical facilities, but more than that the library must also understand the value of the library, relating to this value is certainly something that has not been implemented in Islamic university libraries in Indonesia, this is indicated by the fact that there are still many libraries that prioritize the development of physical facilities, but their value is still being ruled out. The library of Islamic universities in Indonesia in addition to facing very rapid technological developments, also needs to be ready to face changes in user behavior that also change according to the times. Other problems are aspects of the university's mission, namely developing and
\end{abstract}


advancing research. The open access movement is also one of the challenges that must be answered immediately by the Islamic college library. Then the challenge to accommodate the rapid changes in teaching is also greatly influenced by the development of the use of information technology as it is today.

Keywords: Problems, libraries of Islamic universities, Indonesia, era 4.0

\begin{abstract}
Abstrak
Era 4.0 merupakan era revolusi industri teknologi yang secara fundamental akan mengubah paradigma berpikir dan cara kerja. Tulisan ini bertujuan untuk menganalisis apa saja problematika yang dihadapi perpustakaan perguruan tinggi Islam dalam menyongsong era 4.0. Jenis penelitian ini adalah studi literatur. Studi literatur bisa didapat dari berbagai sumber, jurnal, buku, dokumentasi, internet dan pustaka. sedangkan analisis data dengan metode analisis deskriptif. Hasilnya menunjukkan bahwa ada beberapa problematika yang dihadapi perpustakaan perguruan tinggi Islam di Indonesia yaitu bahwa perpustakaan perguruan tinggi Islam tidak hanya mengedepankan peran tradisional dengan menyediakan sarana fisik semata, tetapi lebih dari sekedar itu pihak perpustakaan harus juga memahami value perpustakaannya, berkaitan dengan value ini tentunya merupakan suatu hal yang belum diimplementasikan di perpustakaan perguruan tinggi Islam di Indonesia, hal ini diindikasikan dengan masih banyaknya perpustakaan yang mengedepankan pengembangan sarana fisik semata, akan tetapi valuenya masih dikesampingkan. Perpustakaan perguruan tinggi Islam di Indonesia selain menghadapi perkembangan teknologi yang amat pesat, juga perlu siap menghadapi perubahan dalam perilaku pengguna yang ikut berubah sesuai perkembangan zaman. Problematika lainnya adalah aspek dari misi perguruan tinggi, yaitu mengembangkan dan memajukan penelitian. Gerakan open access juga merupakan salah satu tantangan yang harus segera dijawab oleh pihak perpustakaan perguruan tinggi Islam.
\end{abstract}


Kemudian tantangan untuk mengakomodasi perubahan pesat dalam pengajaran yang juga amat dipengaruhi oleh perkembangan penggunaan teknologi informasi seperti sekarang ini.

Kata Kunci: problematika, perpustakaan perguruan tinggi Islam, Indonesia, era 4.0

\section{A. Pendahuluan}

Topik disrupsi era industry 4.0 yang sedang trend sekarang ini tentunya sangat menarik untuk menjadi bahan diskusi di kalangan akademisi dan praktisi dalam berbagai bidang tak terkecuali perpustakaan dan kepustakawanan. Kehadiran era 4.0 ini selain ada yang gembira, da nada pula yang cemas dan bingung dengan apa yang dilakukan bila era disrupsi 4.0 benar-benar sudah ada di depan mata. Ada yang menolak mentah-mentah dengan berbagai argumen, menghindar, menjauh, cuek, dan menghadapi dengan tenang tanpa gejolak.

Salah satu yang menjadi objek dari disrupsi era 4.0 adalah perpustakaan, yang sejak dulu mempunyai image negatif, sebagai "gudang" dengan segala sebutan yang menempel dan tidak memberikan rasa senang orang yang berkunjung ke perpustakaan. Brand image perpustakaan adalah "gudang" berlangsng sampai tahun 1990, karena tahun itu menjadi tonggak masuknya teknologi di perpustakaan. Perpustakaan dalam menghadapi era disrupsi 4.0 yang secara harfiah digambarkan sebagai suatu sistem yang sudah berjalan aman, nyaman, stabil, dan menyenangkan, semua itu menjadi "tercerabut dari akarnya". Digambarkan seperti tanaman hias yang sedang tumbuh subur, mekar bunganya, enak dipandang mata, tiba-tiba dicabut sampai akar-akarnya terlepas dari tanah. Kemudian tanahnya diratakan dibersihkan, dirabuk dan diganti dengan tanaman bunga yang lebih indah, mempesona dan menarik kupu-kupu, lebah lebih banyak, sehingga semakin ramai dan menyenangkan. 
Era disrupsi 4.0 ada yang mengatakan perpustakaan sudah tidak ada, dan tidak perlu karena diganti dengan perpustakaan tanpa dinding (library without walls), perpustakaan tanpa cetak (library without print collections), semuanya berbentuk digital. Perpustakaan menghadapi kompetitor yang tidak kelihatan yang dapat menimbulkan "paranoid". Sehingga Rhenald Kasali menyatakan bahwa era disrupsi 4,0 merupakan era yang menakutkan dan penuh dengan persaingan ketat, bagi yang tidak siap pasti "tersingkir dan minggir" secara alamiah dari percaturan dan menjadi penonton. Oleh karena itu, era revolusi teknologi yang terjadi sekarang ini, secara fundamental akan mengubah cara hidup, cara bekerja, pola berpikir dan cara bekerja satu sama lain dalam lingkup domestik maupun mondial. Ada satu hal yang paling menonjol dalam derap perubahan ini, yaitu dunia harus merespons perubahan tersebut dengan cara yang terintegrasi dan komprehensif dengan melibatkan seluruh pemangku kepentingan, baik itu pelaku politik global, mulai dari sektor pemerintah sampai sektor swasta, akademik, perusahaan, dan tentu saja masyarakat luas.

Respon yang terintegrasi dan komprehensif tersebut bukan tanpa alasan, sebab era teknologi informasi saat ini sedang berada pada puncak perubahan besar yang sebanding dengan munculnya Revolusi Industri Pertama, Kedua, dan Ketiga. Sekarang kita sudah memasuki ke satu tahapan revolusi industri yang dinamakan Revolusi Industri 4.0. Kehadiran revolusi industri 4.0 telah mempengaruhi segala sektor kehidupan termasuk di dalamnya institusi/lembaga penyedia jasa informasi yang tidak lain adalah perpustakaan perguruan tinggi. Perkembangan terbaru menunjukkan bahwa jika perpustakaan perguruan tinggi juga telah bertransformasi dari 3.0 menjadi 4.0 mengikuti perkembangan zaman saat ini. Sebuah transisi yang begitu cepat mengingat library 3.0 secara perlahan baru diimplementasikan di perpustakaanperpustakaan yang tersebar di seluruh wilayah Indonesia. Perubahan yang cepat ini juga direspon secara cepat dan positif 
oleh pihak perpustakaan, termasuk dalam hal ini perpustakaan perguruan tinggi Islam.

Salah satu isu mendasar saat ini yang tengah dialami oleh berbagai perpustakaan perguruan tinggi dan riset di berbagai negara, termasuk negara yang sudah memiliki sistem perpustakaan yang canggih sekalipun, adalah isu "value of libraries", apa sebenarnya nilai dan makna sebuah perpustakaan di perguruan tinggi? Sebuah riset yang dilakukan Loughborough University di Inggris menemukan bahwa di hampir semua negara Eropa dan Amerika, perpustakaan perguruan tinggi didorong untuk aktif mengumpulkan bukti-bukti konkrit dari peran mereka, bukan saja bukti aktivitas melainkan juga bukti nilai dan pengaruh dari kegiatan itu terhadap misi perguruan tinggi di mana mereka berada.

Di era 4.0 ini, tantangan yang dihadapi pustakawan dan perpustakaan perguruan tinggi Islam di Indonesia tak jauh berbeda dari yang dihadapi rekan-rekan pustakawan perguruan tinggi umumnya di Indonesia, maupun rekan-rekan pustakawan di negara lain, khususnya di negara-negara yang sudah maju dalam kepustakawanan. Revitalisasi peran dan profesionalisme pustakawan merupakan masalah kepustakawanan Islam di Indonesia, selain masalah pendanaan dan pengukuran kualitas yang terstandar ${ }^{1}$. Masalah klasik yang dapat kita temui di perguruan tinggi Islam adalah belum terealisasinya jargon-jargon seperti “jantungnya perguruan tinggi”, terutama karena peran dan posisi perpustakaan di dunia perguruan tinggi pada umumnya masih lebih berupa "pendukung", jauh dari kesan penentu. Ini tidak berarti bahwa perpustakaan diabaikan sama sekali, ada banyak perguruan tinggi Islam besar, baik negeri maupun swasta, yang amat serius mengembangkan sarana dan prasarana perpustakaan mereka. Digitalisasi dan peningkatan akses ke internet, khususnya ke jurnaljurnal eletronik, menjadi salah satu bukti keseriusan tersebut.

1 A.R. Siregar, Perluasan peran perpustakaan perguruan tinggi. Pustaha; jurnal studi perpustakaan dan informasi, 4 (1), 7-11. 2008. (http:// repository.usu.ac.id/bitstream/123456789/16086/1/pus-jun2008-(1).pdf 
Berdasarkan pemaparan di atas, maka penulis tertarik untuk mengangkat tulisan tentang apa saja problematika yang dihadapi perpustakaan perguruan tinggi Islam dalam menghadapi era 4.0. Dimana tulisan ini diharapkan menjadi sumbangsih pemikiran bagi dunia kepustakawanan khususnya bagi perpustakaan perguruan tinggi Islam di Indonesia.

\section{B. Pembahasan}

\section{Era Revolusi Industri 4.0}

Istilah revolusi industri 4.0 berkembang dan diciptakan pertama kali di Jerman tepatnya saat diadakan Hannover Fair pada tahun 2011, dimana industri 4.0 ini mencakup berbagai jenis teknologi, mulai dari 3D printing hingga robotik, jenis material baru serta sistem produksi. Angka empat pada istilah industri 4.0 merujuk pada revolusi yang ke empat. Industri 4.0 merupakan fenomena yang unik jika dibandingkan dengan tiga revolusi industri yang mendahuluinya. Industri 4.0 diumumkan secara apriori karena peristiwa nyatanya belum terjadi dan masih dalam bentuk gagasan. Beberapa negara lain juga turut serta dalam mewujudkan konsep industri 4.0 namun menggunakan istilah yang berbeda seperti Smart Factories, Industrial Internet of Things, Smart Industry, atau Advanced Manufacturing. Walaupun memiliki istilahnya masing-masing, namun keseluruhan istilah ini sendiri mencakup satu jenis kegiatan yang bertujuan sama.

Defenisi mengenai Industri 4.0 ada beragam macam karena masih dalam tahap penelitian dan pengembangan. Kanselir Jerman, Angela Merkel berpendapat bahwa Industri 4.0 adalah transformasi komprehensif dari keseluruhan aspek produksi di industri melalui penggabungan teknologi digital dan internet dengan industri konvensional. Selanjutnya, Schlechtendahl menekankan definisi kepada unsur kecepatan dari ketersediaan informasi, 
yaitu lingkungan industri yang di mana seluruh entitasnya selalu terhubung dan mampu berbagi informasi satu dengan yang lain².

Dari penjelasan diatas dapat ditarik kesimpulan bahwa defenisi industri 4.0 itu sendiri merupakan transformasi sebuah unsur kecepatan dari ketersediaan informasi dari keseluruhan aspek produk di industri melalui kolaborasi teknologi digital yang dibantu dari Sumber Daya Manusia yang memiliki tingkat intelektual yang memadai.

Adapun perkembangan industri sejak dimulainya perkembangan revolusi industri yang pertama pada tahun 1784, dapat dijabarkan sebagai berikut:

1. Revolusi Industri yang pertama (1.0) terjadi sejak tahun 1784 yaitu membahas mengenai cara penggunaan tenaga uap dan air yang menjadi masalah dan sering dialami masyarakat.

2. Revolusi Industri yang kedua (2.0) dimulai pada tahun 1870 disaat hampir 100 tahun revolusi industri yang pertama dilaksanakan. Pada jangka waktu 100 tahun itu listrik sudah diciptakan dan masyarakat mulai berfikir untuk mengembangkan energi listrik tersebut demi kemajuan produksi industri.

3. Revolusi Industri ketiga (3.0) dimulai pada tahun 1970 yaitu membahas penggunaan PLC (Programmable Logic Control) dan sistem IT (Information Technology) untuk otomasi baik dalam segala bidang yang termasuk dalam bidang industri, pada tahun itu komputer sudah mulai diciptakan dan dampak penggunaanya dapat memudahkan pekerjaan sudah dirasakan.

4. Revolusi Industri keempat (4.0) yaitu yang sedang terjadi sekarang, disebutkan bahwa revolusi industri keempat ini yaitu berlakunya penggunaan IoT dan CPS, adapun pengertian IoT (Internet of Things) ialah suatu konsep/

${ }^{2}$ Putu Laxman, Pendit, Peringkat universitas, budaya epistemik dan tantangannya bagi perpustakaan perguruan tinggi. Makalah Seminar Nasional Pengembangan Perpustakaan Akademik, Rabu 12 Agustus 2015. Ciputat: UIN Syarif Hidayatullah. 
scenario(objek) memiliki kemampuan untuk mentransfer data melalui jaringan tanpa memerlukan interaksi manusia ke manusia atau manusia ke komputer dan CPS (Cyber Physical Systems) suatu sistem yang berfungsi untuk melindungi fisik dari sebuah benda maupun lainnya.

Itulah keempat revolusi industri yang pernah terjadi hingga saat ini, yang dimana dapat disimpulkan bahwa dilakukannya sebuah revolusi industri ini saat perkembangan sebuah permasalahan yang terjadi di masyarakat yang mempengaruhi berbagai bidang secara besar-besaran ${ }^{3}$. Perkembangan Library 4.0 sejalan dengan perkembangan Web 4.0 dan Industri 4.0. Perkembangan web 4.0 terlihat dari interface serta fitur-fitur yang tersedia dalam sebuah web, yakni tersedia fitur untuk membaca, menulis, dan mengeksekusi informasi secara bersamaan; agen-agen informasi berbasis intelijen, interaksi antar-web (saling terhubung), koneksi dengan intelijen, dan web berbasis intelijen. Perkembangan pengelolaan informasi perpustakaan pada era library 1.0 hingga library 4.0 dijelaskan lebih lanjut melalui tabel 1 berikut ini ${ }^{4}$.

${ }^{3} \mathrm{NJ}$ Azmar, Masa depan perpustakaan seiring perkembangan revolusi industry 4.0 : mengevaluasi peranan pustakawan. Jurnal Iqra' 10(01): 35-37, 2018.

${ }^{4}$ Noh, Younghee. (2015). Imagining Library 4.0: Creating a Modelfor Future Libraries. The Journal of Academic Librarianship,41(6),789-795. Diunduh dari http://dx.doi.org/10.1016/j.acalib.2015.08,020 
Tabel 1. Perkembangan Pengelolaan Informasi Perpustakaan

\begin{tabular}{|c|c|c|c|}
\hline Library 1.0 & Library 2.0 & Library 3.0 & Library 4.0 \\
\hline $\begin{array}{l}\text { - Waktu antara } \\
\text { 1990-2005 } \\
\text { - Interaksi satu } \\
\text { arah } \\
\text { - Teknologi } \\
\text { MARC dan } \\
\text { HTML } \\
\text { - Publikasi/ } \\
\text { koleksi menjadi } \\
\text { kunci layanan } \\
\text { - Perpustakaan } \\
\text { menjadi sumber } \\
\text { informasi } \\
\text { - Informasi } \\
\text { diperoleh } \\
\text { dengan } \\
\text { membaca } \\
\text { - Petugas sumber } \\
\text { informasi } \\
\text { - Layanan } \\
\text { bersifat tertutup } \\
\text { dan terpusat } \\
\text { pada petugas } \\
\text { (pustakawan) } \\
\text { - PC sebagai } \\
\text { media akses } \\
\text { informasi } \\
\text { - Metadata } \\
\text { MARC sebagai } \\
\text { struktur } \\
\text { pengetahuan }\end{array}$ & $\begin{array}{l}\text { - Waktu antara } \\
\text { 2006-2010 } \\
\text { - Interaksi dua } \\
\text { arah secara } \\
\text { langsung } \\
\text { - Teknologi RSS, } \\
\text { WIKI, Blog, } \\
\text { Ajax, Flikr, } \\
\text { tagging, podcast, } \\
\text { bookmark, } \\
\text { mash-up, \& } \\
\text { toolbar } \\
\text { - Partisipasi, } \\
\text { berbagi, dan } \\
\text { keterbukaan } \\
\text { menjadi kunci } \\
\text { layanan } \\
\text { - Partisipasi } \\
\text { pengguna } \\
\text { menjadi sumber } \\
\text { informasi } \\
\text { - Informasi } \\
\text { diperoleh dari } \\
\text { membaca dan } \\
\text { menulis } \\
\text { - Petugas sumber } \\
\text { informasi } \\
\text { - Layanan } \\
\text { bersifat terbuka, } \\
\text { terpusat, \& } \\
\text { berorientasi } \\
\text { pengguna } \\
\text { - PC dan mobile } \\
\text { phonesebagai } \\
\text { media akses } \\
\text { informasi } \\
\text { - Metadata } \\
\text { MARCXML, } \\
\text { MODS, DOI, } \\
\text { XML/RDF } \\
\text { sebagai struktur } \\
\text { pengetahuan }\end{array}$ & $\begin{array}{l}\text { - Waktu antara 2010- } \\
2020 \\
\text { - Interaksi bersifat } \\
\text { personal dan } \\
\text { terbuka } \\
\text { - Teknologi semantic } \\
\text { search, ontology, } \\
\text { teknologi mobile, } \\
\text { teknologi semantik, } \\
\text { artificial intelligence, } \\
\text { context-awarenes, \& } \\
\text { cloud computing } \\
\text { - Semantic web, } \\
\text { metadata, \& } \\
\text { ontology kunci } \\
\text { layanan } \\
\text { - Mesin/database } \\
\text { menjadi sumber } \\
\text { informasi } \\
\text { - Informasi diperoleh } \\
\text { dari membaca, } \\
\text { menulis, dan } \\
\text { pengalaman } \\
\text { - Petugas \& mesin/ } \\
\text { database sumber } \\
\text { informasi } \\
\text { - Layanan bersifat } \\
\text { terpisah dan } \\
\text { menyebar ke } \\
\text { pengguna } \\
\text { - PC, mobile phone, } \\
\text { iPad, \& peralatan } \\
\text { digital lain sebagai } \\
\text { media akses } \\
\text { informasi } \\
\text { - Metadata FRBR, } \\
\text { ontology, \& } \\
\text { struktur semantik } \\
\text { sebagai struktur } \\
\text { pengetahuan } \\
\text { anala }\end{array}$ & $\begin{array}{l}\text { - Optimasi } \\
\text { layanan library } \\
3.0 \text { dengan } \\
\text { penguatan pada } \\
\text { integrasi dan } \\
\text { konektivitas } \\
\text { layanan } \\
\text { perpustakaan } \\
\text { virtual untuk } \\
\text { generasi masa } \\
\text { mendatang } \\
\text { - Fitur layanan } \\
\text { library } 4.0 \\
\text { berbasis web } \\
4.0 \text { yang berisi } \\
\text { intelligent, } \\
\text { makerspace, } \\
\text { teknologi, } \\
\text { open source, } \\
\text { big data, cloud } \\
\text { computing, } \\
\text { augmented } \\
\text { reality, tampilan } \\
\text { state-of-the-art, } \\
\text { \& librarian } 4.0 \text {. }\end{array}$ \\
\hline
\end{tabular}

Sumber: Noh (2015, hlm.790) 


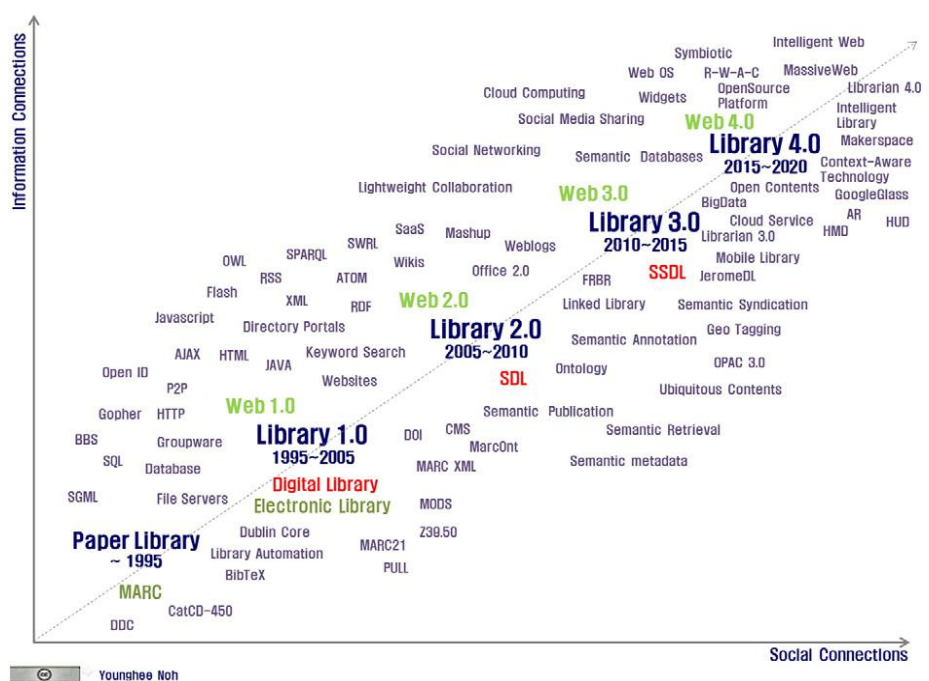

Sumber: Noh, 2015, hlm.795

Gambar Perkembangan Library 1.0 menuju Library 4.0

\section{Perpustakaan Perguruan Tinggi dan Era Industri 4.0}

Institusi perpustakaan menjadi elemen penting dari sebuah perguruan tinggi. Urgensinya perpustakaan tersebut disebabkan karena untuk melaksanakan misi Tri Dharma Perguruan Tinggi, yaitu: pendidikan, pengajaran, penelitian, dan pengabdian kepada masyarakat, dengan tujuan akhirnya adalah mencerdaskan kehidupan bangsa, memajukan serta menyebarkan ilmu pengetahuan dan teknologi dalam rangka memberdayakan bangsa Indonesia secara kontinu, maka mau tak mau keberadaan perpustakaan diperlukan untuk menyediakan berbagai sumber informasi.

Setiap perguruan tinggi wajib memiliki perpustakaan. Perpustakaan menjadi salah satu syarat berdirinya perguruan tinggi. Dalam Undang-undang Nomor 20 Tahun 2003 tentang Sistem Pendidikan Nasional pada Pasal 55 menyebutkan bahwa salah satu syarat untuk menyelenggarakan perguruan tinggi harus memiliki perpustakaan. Keberadaan perpustakaan perguruan tinggi sebagai Unit Pelaksana Teknis (UPT) yang bersama-sama dengan unit lain adalah melaksanakan Tri Dharma Perguruan 
Tinggi dengan tugas khusus menghimpun, memilih, mengolah, merawat, serta melayani sumber informasi kepada lembaga induk khususnya dan masyarakat akademis pada umumnya ${ }^{5}$.

Perpustakaan yang berdiri di tengah-tengah perguruan tinggi seperti itu, baik di universitas, institut, sekolah tinggi, ataupun akademis dengan bersama-sama mengemban misi Tri Dharma Perguruan Tinggi tersebut, secara khusus disebut dengan perpustakan perguruan tinggi. Lebih luas lagi yang termasuk perpustakaan perguruan tinggi adalah semua perpustakaan yang terdapat pada perguruan tinggi, juga badan bawahannya ataupun lembaga yang berafiliasi dengan perguruan tinggi, seperti: perpustakaan pada tingkat fakultas, jurusan, program studi, juga perpustakaan yang berada di bawah unit atau pusat, seperti: pusat penelitian, pusat-pusat studi, dan lain-lain. Jika secara umum perpustakaan di perguruan tinggi bertugas dan bertujuan memperlancar misi dan tugas perguruan tinggi dalam melaksanakan Tri Dharma Perguruan Tinggi tersebut, maka secara mendetail perpustakaan perguruan tinggi bertujuan untuk:

a. Memenuhi keperluan informasi masyarakat perguruan tinggi, lazimnya pengajar dan mahasiswa;

b. Menyediakan bahan pustaka rujukan (referensi) pada semua tingkat akademik, artinya mulai dari mahasiswa tahun pertama hingga mahasiswa pascasarjana dan pengajarnya;

c. Menyediakan ruang belajar untuk pengguna perpustakaan;

d. Menyediakan jasa peminjaman yang tepat guna bagi berbagai jenis pemakai;

e. Menyediakan jasa informasi aktif yang tidak saja terbatas pada lingkungan perguruan tinggi tetapi juga lembaga industri local ${ }^{6}$.

Perpustakaan tak luput dari mengikuti perkembangan informasi dan teknologi yang semakin merangkak cepat, sehingga membuat perpustakaan diwajibkan juga ikut berkembang.

5 Indonesia, Undang-Undang No. 20 Tahun 2003 tentang Sistem Pendidikan Nasional Pasal 55. Jakarta: Departemen Pendidikan Nasional. 2003. Jakarta, 1991.

${ }^{6}$ Sulistyo Basuki, Pengantar Ilmu Perpustakaan. Gramedia Pustaka 
Terutama saat ini sedang gencar-gencarnya perkembangan mengenai revolusi industri 4.0, yang dimana revolusi ini sudah dibicarakan oleh beberapa negara di dunia. Munculnya revolusi industri 4.0 membuat berlakunya penggunaan IoT dan CPS, adapun pengertian IoT (Internet of Things) adalah suatu konsep/ skenario dimana suatu objek yang memiliki kemampuan untuk mentransfer data melalui jaringan tanpa memerlukan interaksi manusia ke manusia atau manusia ke komputer dan CPS (Cyber Physical Systems) adalah suatu sistem yang berfungsi untuk melindungi fisik dari sebuah benda maupun lainnya. Jika hal ini dibiarkan tanpa adanya persiapan maka akan mempengaruhi fungsi pustakawan secara khusus yaitu melayani serta menyediakan sumber koleksi yang berkualitas dan terbaru, agar siap menghadapi perkembangan teknologi informasi. Selain itu di perpustakaan perguruan tinggi juga harus mengarahkan kebijakan apa yang akan diambil untuk menghadapi revolusi industri 4.0 yang secara apriori belum terjadi dan masih dalam bentuk gagasan. Dalam hal ini dibutuhkan Sumber Daya Manusia yang professional untuk mewujudkan perpustakaan agar siap bersaing menghadapi perkembangan zaman. Adapun kebijakan seorang pemimpin dalam perpustakaan yang harus mengapresiasi revolusi industri 4.0 sebagai pengingat tugas utama perpustakaan perguruan perguruan tinggi yaitu menyediakan jasa informasi aktif tidak hanya untuk kalangan mahasiswa dan dosen tapi masyarakat sekitarnya juga akan ikut merasakan kebijakan tersebut.

\section{Kondisi Perpustakaan Perguruan Tinggi Islam di Indonesia}

Penulis belum memiliki data yang lengkap tentang kondisi perpustakaan perguruan tinggi Islam di Indonesia dua tahun belakangan ini. Namun dengan melihat secara sepintas, penulis segera agak yakin berpendapat bahwa secara umum perpustakaan perguruan tinggi Islam di Indonesia masih perlu berjuang keras untuk menyelaraskan diri dengan perkembangan lembaga induknya. Sementara lembaga induknya itu sendiri juga sedang menghadapi berbagai persoalan dalam rangka transformasi 
menjadi penggerak pendidikan tinggi Islam, baik untuk tujuantujuan nasional maupun untuk internasional.

Fenomena world class university dan research university yang kemudian diterjemahkan ke dalam konteks perpustakaan menjadi world class university library and research university library, menurut hemat dan pengetahuan penulis, juga belum memiliki landasan yang terlalu jelas. Sebelum fenomena ini muncul, perpustakaan perguruan tinggi Islam di Indonesia pada umumnya sedang berbenah untuk memasuki era digital. Dalam hal ini, konsep perpustakaan digital sudah lebih jelas dipahami oleh para pengelola. Nampaknya konsep world class university library dan research university library merupakan semacam pencabangan atau terusan saja dari konsep perpustakaan digital di perguruan tinggi Islam. Agar lebih jelas, pencabangan ini sebaiknya dilektakkan dalam konteks pengembangan kapasitas riset.

Terlepas dari ketiadaan konsep yang jelas tersebut, penulis juga melihat bahwa problematika yang dihadapi pustakawan perguruan tinggi Islam di Indonesia tak jauh berbeda dari yang dihadapi rekan-rekan pustakawan perguruan tinggi umum, maupun rekan-rekan pustakawan di negara lain, khususnya di negara-negara yang sudah maju dalam kepustakawanan. Revitalisasi peran dan profesionalisme pustakawan merupakan masalah kepustakawanan Islam di Indonesia, selain problem pendanaan dan pengukuran kualitas yang terstandar ${ }^{7}$. Masalah klasik yang dapat kita temui di perguruan tinggi Islam adalah belum terealisasinya jargon-jargon seperti “jantungnya perguruan tinggi”, terutama karena peran dan posisi perpustakaan di dunia akademik (perguruan tinggi) masih lebih berupa pendukung, jauh dari kesan penentu. Ini tidak berarti bahwa perpustakaan diabaikan sama sekali, ada banyak perguruan tinggi Islam besar, baik negeri maupun swasta, yang amat serius mengembangkan sarana dan prasarana perpustakaan mereka.

${ }^{7}$ P. Suparmo, Menggagas kualitas perpustakaan perguruan tinggi. Visi Pustaka, 14 (3), 51-59. 2012. 
Digitalisasi dan peningkatan akses ke internet, khususnya ke jurnaljurnal eletronik, menjadi salah satu bukti keseriusan tersebut.

Namun tentu saja peran perpustakaan tidak dapat hanya ditunjukkan dalam bentuk penyediaan sarana fisik. Salah satu aspek penting dalam menegaskan nilai penting dari perpustakaan adalah bukti-bukti yang teranalisis tentang sumbangan jasa maupun koleksinya bagi kemajuan penelitian dan pengajaran di lembaga induk. Saat ini sebenarnya sudah tersedia Standar Nasional Indonesia Perpustakaan Perguruan Tinggi (SNI 7330:2009) dan proses akreditasi oleh Perpustakaan Nasional Republik Indonesia maupun Badan Akreditasi Nasional Perguruan Tinggi sebagai sarana untuk menjamin mutu dari perpustakaan. Kedua perangkat ini sebenarnya dapat dijadikan ukuran untuk peran perpustakaan tinggi Islam, asalkan tidak terlalu menekankan kesiapan teknis dan berorientasi kepada pemustaka (bukan ke penyelenggara). Sebagaimana dikatakan Sulistyo Basuki akreditasi di Indonesia cenderung bersifat lebih teknis, dan masih bersifat sukarela. Hal ini tentunya akan mengurangi kredibilitas di mata pemangku kepentingan lain.

Perpustakaan dan pustakawan perguruan tinggi Islam nampaknya harus terus membiasakan diri dengan survei kepuasan pemustaka, evidence-based practice, benchmarking, dan berbagai perangkat evaluasi lainnya. Salah satu rekomendasi untuk para pustakawan akademik di Amerika Serikat mungkin dapat pula diadopsi ${ }^{8}$. Menurut rekomendasi tersebut, perpustakaan dan pustakawan perlu terlebih dahulu menegaskan apa saja outcomes yang relevan dengan misi dan strategi lembaga induk, sebelum mengukur sejauh mana mereka sudah mencapainya. Para pustakawan dapat menyusun kerangka penilaian kinerja yang mengaitkan outcomes perpustakaan dengan berbagai area seperti

8 Association of College and Research Libraries, Value of Academic Libraries: A Comprehensive Research Review and Report. Research by Megan Oakleaf. Chicago: Association of College and Research Libraries, 2010. (http:// $w w w . a l a . o r g / a c r l / s i t e s / a l a . o r g . a c r l / f i l e s / c o n t e n t / i s s u e s / v a l u e / v a l \_r e p o r t . p d f$, diakses 30 Mei 2019). 
produktivitas riset para dosen, pencapaian dan prestasi pengajar maupun peserta didik, dan bahkan dengan keseluruhan kualitas kinerja lembaga induk.

Demikian pula, jika perguruan tinggi Islam di Indonesia saat ini lebih suka mengejar peringkat di salah satu skema pemeringkatan seperti webometrics, maka sebaiknya dilakukan pembuktian bahwa hal-hal yang dinilai untuk sistem pemeringkatan tersebut (visibility, size of website, rich files, dan scholar) relevan dengan kontribusi perpustakaan perguruan tinggi Islam yang bersangkutan. Kajian keselarasan antara peringkat perguruan tinggi dan peringkat perpustakaan dapat dilakukan, sebagaimana yang pernah dilakukan Muntashir, yang menyatakan bahwa perpustakaan memiliki peran terhadap peringkat perguruan tinggi negeri di Indonesia9 Analisis seperti ini dapat dipakai sebagai dasar untuk melakukan analisis lebih lanjut terhadap peran perpustakaan dan pustakawan, misalnya dalam meningkatkan minat dan kebiasaan dosen atau peneliti mengisi repositori institusional pada suatu perguruan tinggi Islam.

Jika pustakawan dan pengelola perpustakaan perguruan tinggi Islam telah dapat meletakkan dasar-dasar revitalisasi peran institusinya, maka sebenarnya ada banyak solusi dan inisitif yang dapat dilakukan. Salah satunya adalah inisiatif literasi informasi (Information literacy) yang dikaitkan dengan kapasitas riset civitas akademika. Mengingat kapasitas riset ini merupakan salah satu isu penting dalam menentukan kualitas suatu perguruan tinggi, maka sangatlah strategis jika pustakawan menawarkan program-program yang dapat membantu peningkatan kapasitas tersebut. Contohnya dapat dilihat dalam bentuk apa yang dilakukan oleh Loughborough Uinversity (Inggris) di negara-negara Afrika. Dalam laporannya, Hepwort \& Duvigneau menyatakan bahwa ada kaitan yang erat antara literasi informasi, kemampuan belajar, dan berpikir kritis (critical thinking). Untuk mencapai kondisi ideal, maka program-

9 Muntashir, Analisis webometrics pada perpustakaan perguruan tinggi negeri di Indonesia. Visi Pustaka, 14 (2), 39-49. 2012. 
program literasi informasi di perguruan tinggi harus dilakukan oleh pustakawan yang selain memang terampil menjadi tutor dan fasilitator, tetapi juga mempunyai semacam mandat kepercayaan dari pihak peserta ${ }^{10}$. Dalam konteks Indonesia, hal inilah terakhir yang mungkin akan menjadi halangan. Dosen/ peneliti mungkin beranggapan bahwa mereka tidak memerlukan bantuan, apalagi wejangan dan pelatihan dari pustakawan. Walaupun hal ini dapat diatasi dengan meminta bantuan pakar atau pemimpin pendapat (opinion leader) di kalangan dosen/ peneliti sendiri, namun dalam jangka panjang hubungan yang kurang selaras ini memerlukan saling pemahaman yang lebih pasti dari masing-masing pihak. Hal inilah tentunya harus menjadi perhatian bagi perpustakaan perguruan tinggi Islam di Indonesia.

Perpustakaan-perpustakaan di Inggris sendiri, sebagai salah satu negara yang memiliki sistem perguruan tinggi dan perpustakaan yang maju, mengakui bahwa institusi mereka tetap perlu "contributes directly to the institution's academic mision.... Dana yang cukup besar, yang jumlahnya mencapai 682 juta poundsterling untuk anggaran 2010-2011, harus mereka pertanggungjawabkan untuk sepenuhnya melayani kebutuhan para akademisi dan mahasiswa, khususnya dalam bentuk layanan berbasis teknologi informasi. Pustakawan-pustakawan di negeri itu boleh dikatakan beruntung mendapat dukungan yang begitu besar, namun tetap merasa perlu meningkatkan profesionalisme mereka agar dapat lebih terlibat dalam misi-misi riset perguruan tinggi dimana mereka berada ${ }^{11}$.

Negara lain yang juga sudah memiliki sistem perpustakaan yang maju dan canggih yaitu Amerika Serikat, mengalami hal yang

10 M. Hepworth \& S. Duvigneau, Building Research Capacity: Enabling Critical Thinking Through Information Literacy in Higher Education in Africa, Brighton, UK: the Institute of Development Studies, 2012. (http://opendocs.ids.ac.uk/opendocs/bitstream/handle/123456789/2301/ BuildingResearchCapacityR1.pdf).

11 Putu Laxman Pendit, Peringkat universitas, budaya epistemik dan tantangannya bagi perpustakaan perguruan tinggi. Makalah Seminar Nasional Pengembangan Perpustakaan Akademik, Rabu 12 Agustus 2015. Ciputat: UIN Syarif Hidayatullah. 
sama. Dalam sebuah kesimpulan dari pengamatan terhadap kondisi perpustakaan di negeri itu, ACRL menyatakan bahwa fungsi pustakawan perguruan tinggi sebagai connectors and integrators telah menjadi pusat perhatian dari semua pemangku kepentingan ${ }^{12}$. Dalam situasi yang semakin kompleks karena perkembangan dan perubahan yang amat pesat di dunia perguruan tinggi negara itu, para pustakawan dituntut meningkatkan kemampuan mereka tidak hanya sebagai penghimpun dan pengelola pengetahuan, tetapi juga sebagai komunikator dan promotor dalam proses penelitian maupun pengajaran.

Selain memerlukan revitalisasi peran tradisionalnya, perpustakaan perguruan tinggi pada saat yang sama juga mendapat tantangan baru, sebab pengembangan ilmu pada umumnya dan kegiatan perguruan tinggi pada khususnya telah dipengaruhi oleh perkembangan teknologi informasi yang sangat pesat. Kembali sebagaimana ditengarai ACRL, pada tahun 2012 ada sepuluh hal yang mencirikan perubahan mendasar dan strategis di bidang perpustakaan perguruan tinggi, tiga di antaranya amat berkaitan dengan teknologi informasi, yaitu:

1. Salah satu peran sentral perpustakaan perguruan tinggi tentu saja adalah dalam komunikasi antar ilmuwan (scholarly communication). Di masa kini, peran ini semakin penting dan sekaligus telah mengalami perubahan amat mendasar. Penyebab utama perubahan itu adalah penggunaan teknologi informasi dalam jurnal, monograf ilmiah, buku teks, dan material digital. Perkembangan gerakan open akses, kesediaan para penulis untuk membayar agar artikelnya bisa diakses secara gratis, dan nasib yang tidak jelas dari "Big Deals", merupakan beberapa isu yang kini sedang mengubah posisi dan peran perpustakaan perguruan tinggi dalam komunikasi antar ilmuwan.

${ }^{12}$ Association of College and Research Libraries, Connect, Collaborate, and Communicate: A Report from the Value of Academic Libraries Summits. Prepared by Karen Brown and Kara J. Malenfant. Chicago: Association of College and Research Libraries, 2012. Diakses 10 Juni 2019. (www.acrl.ala.org/value. 
2. Perawatan dan penyediaan data (data curation) menjadi fitur baru yang amat "menantang" perpustakaan perguruan tinggi, khususnya dalam konteks riset. Penggunaan teknologi informasi (komputer) dalam penelitian saat ini, baik di bidang ilmu pasti, alam maupun sosial, telah berpotensi menimbulkan bertambahnya bentuk data digital dalam jumlah besar, baik yang umum dipakai seperti data spreadsheet untuk statistik, maupun data spesifik seperti peta geospatial dan model-model grafis. Badan-badan pemberi dana penelitian di negara-negara maju, seperti Amerika Serikat dengan National Science Foundation, bahkan sudah mensyaratkan agar semua penelitian yang dibiayai dana publik menyertakan rencana kurasi data mereka di perpustakaan di institusi dari mana mereka berasal.

3. Masih terkait dengan butir 2 di atas, perpustakaan perguruan tinggi dan riset saat ini harus mulai merancangbangun kebijakan dan menerapkan praktik preservasi digital (digital preservation) yang memadai. Jumlah koleksi digital, baik yang merupakan hasil konversi maupun yang terlahir digital (born digital) akan semakin banyak dan merupakan aset penting bagi perguruan tinggi. Berbeda dari preservasi bahan pustaka konvensional, preservasi digital memerlukan teknologi dan prosedur yang berbeda. Pustakawan perguruan tinggi amat dituntut untuk memahami karakteristik materi digital dan teknologi penggeraknya, agar dapat secara memadai mengelola program preservasi ini. Dalam hal ini, kerjasama dengan teknolog dan pengelola sistem informasi perguruan tinggi merupakan hal yang mutlak harus digalakkan. ${ }^{13}$

${ }^{13}$ Association of College and Research Libraries, Connect, Collaborate, and Communicate: A Report from the Value of Academic Libraries Summits. Prepared by Karen Brown and Kara J. Malenfant. Chicago: Association of College and Research Libraries, 2012. Diakses 10 Juni 2019. (www.acrl.ala. org/value. 
Selain menghadapi perkembangan teknologi yang amat pesat, perpustakaan perguruan tinggi juga perlu siap menghadapi perubahan dalam perilaku pengguna yang ikut berubah sesuai perkembangan zaman. Hal ini sebenarnya sudah diantisipasi sejak awal tahun 2000 melalui berbagai kajian perilaku (information behaviour) yang memang merupakan salah satu kajian tradisional pustakawan perguruan tinggi. Kajian-kajian tersebut secara konsisten menunjukkan bahwa perilaku informasi para ilmuwan di berbagai bidang telah mengalami transformasi berkat ketersediaan sumber daya digital, walaupun langkah-langkah utama dalam mencari, menemukan, dan menggunakan informasi mereka tidak mengalami banyak perubahan. Dari sisi pandang kepustakawanan, perubahan terbesar justru pada pola komunikasi dan trust relationships antara ilmuwan dan pustakawan, serta perubahan sikap peneliti terhadap perpustakaan sebagai sumberdaya informasi dan pengetahuan. Akses ke internet yang leluasa dan ketersediaan berbagai sumberdaya digital di luar perpustakaan telah amat mempengaruhi peran dan posisi perpustakaan di dalam melayani komunitas peneliti. Di sebagian perguruan tinggi, peran perpustakaan justru semakin meningkat, sementara di perpustakaan lain malah berkurang, sebagaimana diungkapkan Bradley, Haines dan Xuemei. ${ }^{141516}$

Khusus dalam kaitannya dengan komunikasi antar ilmuwan (scholarly communication) dan gerakan open access, sebuah penelitian tentang perilaku ilmuwan yang dilakukan Berneus dkk (2012) memperlihatkan hasil menarik tentang manfaat open access terhadap ilmuwan yang tergolong "first movers" di masa transisi. Menurut penelitiannya, akses yang terbuka memang meningkatkan

${ }^{14}$ Bradley M, Hemminger, B.M., Lu, D., Vaughan, K.T., dan Adams, S.J, Information Seeking behavior of academic scientists. Journal of the American Society for Information Science and Technology, 58 (14), 2007, h. 2205-2225.

${ }_{15}$ Haines, L.1., Light, J., \& O’Malley, D, Information-seeking behavior of basic science researchs: implications for library services. Journal for Medical Library Association, 98 (1), 2010, h. 73-81.

16 G. Xuemei, Information-seeking behavior in the digital age: a multidisciplinary study of academic researchs. College \& Research Libraries, 71 (5), 2010, h. 435-455. (http://crl.acrl.org/content/71/5/435.full.pdf+html. 
author's impact dalam bentuk peningkatan sitasi. Pada umumnya hal ini terjadi di masa transisi menuju open access. Di dalam komunitas ilmuwan yang tergolong "non-Open Access community" (mayoritas ilmuwan belum memanfaatkan open access), ilmuwan "first movers" seringkali lebih cepat dikutip, walau harus juga diingat bahwa artikel berkualitas rendah yang "uncitable" akan serta merta berubah menjadi yang berpotensi dikutip hanya karena dimuat di jurnal-jurnal open access. Selain itu pada masa-masa awal penggunaan open access, penelitian Berneus dan kawan-kawan memperlihatkan bahwa para ilmuwan tetap menggunakan pola komunikasi ilmiah tradisional yang berbasis jurnal.

Sementara itu hasil penelitian Creaser dkk (2010) menyatakan bahwa para ilmuwan memang menerima gagasan open access, walaupun masih belum mengetahui secara terperinci. Mereka memahami potensi keterbukaan ini bagi komunikasi ilmiah, namun juga tak terlalu dapat merinci apa saja sesungguhnya peran open access bagi kegiatan mereka. Hanya sedikit responden yang tidak tahu sama sekali peran tersebut, tetapi lebih dari setengah responden hanya menganggap bahwa open access akan menjadi penantang bagi komunikasi klasik yang selama ini dilakukan melalui jurnal berbayar. Sebagian ilmuwan tetap peduli pada fungsi jurnal (open access maupun tidak) untuk penyebarluasan hasil karya mereka, untuk membangun reputasi mereka yang dikaitkan dengan reputasi jurnal itu sendiri. Mereka juga masih sangat menghargai proses peer review dan hanya sedikit yang menganggap open access akan mengancam proses tersebut.

Kedua hasil penelitian di atas dapat dijadikan contoh bahwa di dalam kenyataan kehidupan dan perilaku ilmuwan sehari-hari nampaknya open access akan tetap berkembang bersama dengan kebiasaan "tradisional" yang sudah terbangun dalam tradisi komunikasi ilmiah berbasis jurnal. Kajian Jingfeng tampaknya membenarkan hal ini. Ia menyimpulkan bahwa biar bagaimana pun open access sebagai sebuah model baru dalam komunikasi ilmiah tetap perlu berdampingan dengan sistem lama 
yang sudah mentradisi. ${ }^{17}$ Sebagai sebuah model komunikasi baru, open access hanya dapat diterima jika perilaku para "insiders" (ilmuwan, komunitas ilmu) telah sepenuhnya dipahami oleh "outsiders" (pengambil keputusan, pustakawan) sehingga strategi pengembangan model baru ini dapat dikembangkan secara lebih tepat.

Khusus dalam konteks kepustakawanan, maka kenyataan dalam kegiatan dan perilaku ilmuwan tersebut menegaskan kembali perlunya pustakawan tetap mengasah pemahaman mereka tentang komunitas ilmuwan. Kalau perlu para pustakawan sendiri juga harus menunjukkan sikap dan perilaku ilmuwan yang pro open access. Sebagaimana dikatakan oleh Mercer (2011), setidaknya ada 5 langkah strategis yang diperlukan dalam rangka ini, yaitu:

1. Penajaman program-program pendidikan kesarjanaan IP\&I, terutama untuk memahami secara utuh konsep-konsep seperti hak cipta, fair use, dan juga author rights, selain juga mengerti sepenuhnya cara kerja komunikasi ilmiah. Para pustakawan perguruan tinggi perlu memahami segala aspek teknis tentang publikasi ilmiah, selain juga berupaya ikut serta dalam proses penelitian dan penulisan ilmiah.

2. Terapkan program-program berkelanjutan dalam bentuk pelatihan dan penyegaran tentang komunikasi ilmiah di perpustakaan-perpustakaan perguruan tinggi. Para pustakawan diharapkan terjun langsung dalam kegiatankegiatan yang menyangkut komunikasi ilmiah, termasuk dalam perencanaan penelitian, penerbitan jurnal, dan penggalangan komunikasi antar ilmuwan.

3. Secara aktif mempromosikan institutional repositories, tak hanya sebagai sarana teknologi penghimpun karya ilmiah melainkan juga manfaatnya dalam meningkatkan impact factors bagi peneliti dan penulis. Pustakawan sangat perlu

17 X. Jingfeng, An anthropological emic-etic perspective on open access practices. Journal of Documentation, 67 (1), 2011, h. 75-94. Doi: 10.1108/00220411111105461. 
memahami penggunaan sarana pemantauan yang dapat dimanfaatkan oleh peneliti dan penulis untuk mengukur sendiri keuntungan yang diperolehnya jika menggunakan sarana open access.

4. Ikut terlibat dalam pengembangan (dan perubahan) sistem publikasi ilmiah. Pustakawan harus dapat ikut bernegosiasi dengan penerbit jurnal, bersama-sama institusi penelitian di perguruan tingginya, untuk memastikan terciptanya model-model penerbitan jurnal yang pro open access.

5. Memastikan dukungan kebijakan dari perguruan tinggi dan perpustakaan sebagai tempat bernaung para pustakawan yang ingin menggerakkan open access. ${ }^{18}$

Berdasarkan uraian di atas dapat kiranya dipahami bahwa betapa besar dan berat tantangan yang dihadapi perpustakaan dan pustakawan perguruan tinggi. Ini juga baru satu aspek dari misi perguruan tinggi, yaitu mengembangkan dan memajukan penelitian. Belum lagi tantangan yang dihadapi untuk mengakomodasi perubahan pesat dalam pengajaran yang juga amat dipengaruhi oleh perkembangan penggunaan teknologi informasi seperti sekarang ini.

Menyikapi perkembangan teknologi informasi dan dunia kepustakawanan, Direktur Jenderal Pendidikan Islam Kementerian Agama RI Prof. Kamaruddin Amin, dalam beberapa kesempatan selalu menekankan betapa pentingnya keberadaan perpustakaan bagi perguruan tinggi. Sehingga beliau menyatakan ketika beliau berkungjung ke perguraun tinggi luar negeri, maka hal pertama yang diajak oleh pihak perguruan tinggi adalah mengunjungi perpustakaan. Hal ini berbeda dengan yang terjadi di Indonesia, maka hal pertama yang dikunjungi atau dilihat adalah tanah yang

${ }_{18}$ Putu Laxman Pendit, Peringkat universitas, budaya epistemik dan tantangannya bagi perpustakaan perguruan tinggi. Makalah Seminar Nasional Pengembangan Perpustakaan Akademik, Rabu 12 Agustus 2015. Ciputat: UIN Syarif Hidayatullah. 
akan dibebaskan. ${ }^{19}$ Pernyataan ini mengindikasikan bahwa beliau sangat concern dan memiliki perhatian yang serius terhadap perpustakaan, terutama perpustakaan yang berada di bawah naungan direktorat jenderal pendidikan Islam.

Di era 4.0 saat ini, perpustakaan perguruan tinggi harus bisa menjangkau seluruh civitas akademika perguruan tinggi melalui penggunaan teknologi informasi, sehingga dampak positifnya terhadap pengembangan sumber daya manusia dan kesejahteraan masyarakat bisa dirasakan. Begitu juga halnya, jika berbicara dalam konteks perpustakaan perguruan tinggi Islam, maka perpustakaan perguruan tinggi Islam harus memberikan dampak yang positif bagi masyarakat kampus.

Perpustakaan telah mengalami beberapa kali evolusi dalam perkembangannya. Jika pada awalnya perkembangannya perpustakaan berfokus pada koleksi pustaka dan layanan, kini telah bergeser pada nilai tambah. ${ }^{20}$ Dengan demikian, perkembangan perpustakaan pada tahapan berikutnya sangat mungkin terjadi dan bisa diciptakan. Hal ini diperlukan untuk menyesuaikan dengan perkembangan pemustaka dan perkembangan teknologi informasi. Harapannya, berbagai penyesuaian dapat membuat perpustakaan semakin berharga dan memberi dampak yang semakin besar bagi dunia pendidikan.

Keberadaan kecerdasan buatan atau artificial intelligence (AI), big data, internet of things (IoT), layanan berbasis cloud, dan alat-alat cerdas, sebagai ciri dari Revolusi Industri 4.0 akan membuat banyak perubahan dunia pendidikan (Grewal, Motyka, \& Levy, 2018). Akibatnya, pengelola perpustakaan di berbagai belahan dunia menebak-nebak terobosan berikutnya yang harus dilakukan dalam rangka menyesuaikan kebutuhan pemustaka dengan kemajuan teknologi informasi. Hal tersebut tidak ada yang

${ }^{19}$ Kamaruddin Amin, Sambutan pada acara Peletakan Batu Pertama Pembangunan Gedung Perpustakaan IAIN Curup, Juli 2017.

${ }_{20}$ Younghee Noh, Imagining Library 4.0: Creating a Modelfor Future Libraries. The Journal of Academic Librarianship,41(6),2015, h. 789-795. http:// dx.doi.org/10.1016/j.acalib.2015.08,020 
salah. Hanya saja, melihat kebutuhan nyata yang ada di dalam dunia pendidikan justru harus menjadi fokus dalam pengembangan perpustakaan. Teknologi informasi dapat mewujudkan apabila kebutuhan dan solusi yang dirancang sudah mulai terbentuk.

Namun berbicara mengenai perpustakaan, tidak hanya membahas mengenai koleksi pustaka yang dimiliki dan pengembangan koleksi pustaka dalam bentuk digital. Masih ada pustakawan yang dapat menjadi nilai jual dan penguat dari keberadaan perpustakaan. Apalagi saat ini koleksi buku ataupun buku elektronik semakin mudah didapatkan dengan prosedur peminjaman dan pengembalian yang lebih mudah dan mandiri, bahkan tidak merepotkan pemustaka. Sebagai contoh, aplikasi iJakarta, iJateng, iPusnas, dan sejenisnya membuat pemustaka merasa dimanjakan dalam peminjaman buku ataupun pengembalian secara otomatis ketika masa waktu peminjaman sudah habis. Oleh karena itu, perlu dirumuskan nilai tambah yang menjadi kekuatan dari perpustakaan masing-masing. Konsep Library 4.0 yang mengadopsi unsur-unsur utama dalam Revolusi Industri 4.0 perlu dikembangkan oleh para pengambil kebijakan di dunia perpustakaan perguruan tinggi Islam.

Gambaran perpustakaan tradisional dilengkapi bukubuku dari masa lalu sampai masa kini yang tertata rapi berjajar di rak-rak, juga meja-meja untuk belajar mandiri, sering ditemui di berbagai lokasi. Mungkin ada juga situasi perpustakaan yang terlihat lebih modern dengan sejumlah komputer untuk akses digital ke internet ataupun pustaka digital. Namun suasana yang sepi dan sunyi menjadi ilustrasi perpustakaan yang melekat pada banyak orang sehingga menjadikannya sebagai tempat untuk "mojok" atau menghindari keramaian. Kondisi-kondisi seperti ini harus disikapi secara serius oleh para pimpinan perpustakaan perguruan tinggi Islam, pimpinan lembaga perguruan tinggi Islam, para pemerhati kepustakawanan Islam, bahkan para pimpinan di Direktorat Pendidikan Tinggi Keagamaan Islam (PTKI). 


\section{Problematika Perpustakaan Perguruan Tinggi Islam di Indonesia Menghadapi Era 4.0}

Era 4.0 seperti sekarang ini yang ditandai dengan digitalisasi, 'artificial intellegence, 'internet of things' serta 'big data' memainkan peranan penting dalam berbagai aspek kehidupan manusia. Perpustakaan di perguruan tinggi Islam pun mau tak mau harus beradaptasi serta berevolusi sehingga tidak terlindas perubahan zaman. Oleh karena itu, saat ini perpustakaan perguruan tinggi Islam tidak bisa lagi dikelola secara konvensional, akan tetapi harus bertransformasi mengikuti perkembangan teknologi agar dapat menjawab kebutuhan civitas akademika perguruan tinggi Islam. Perpustakaan perguruan tinggi Islam ke depannya tidak hanya menjadi tempat berkumpul untuk membaca buku ataupun mencari informasi, namun perpustakaan perguruan tinggi Islam dapat menjadi working space tempat munculnya inovasi-inovasi baru yang brillian dan bermanfaat bagi pengembangan keilmuan Islam.

Perpustakaan perguruan tinggi Islam di era 4.0 seperti sekarang ini, harus mampu bertransformasi jika ingin relevan dengan zaman dan tidak ketinggalan zaman. Sejatinya perpustakaan perguruan tinggi Islam tidak hanya menjadi tempat koleksi buku dan sumber referensi saja, namun lebih dari sekedar itu juga sebagai pusat sumber ilmu pengetahuan (resources of knowledge centre). Hal ini tentunya akan mendukung perpustakaan untuk berangsur menjadi tempat berinteraksi dengan komunitas sosial serta working space tempat tumbuhnya inovasi baru yang produktif dan konstruktif. Karena walau bagaimanapun kondisi perkembangan zaman, Perpustakaan perguruan tinggi Islam senantiasa tetap memegang peranan penting sebagai sumber ilmu pengetahuan walaupun dunia terus mengalami perkembangan. Perpustakaan perguruan tinggi Islam merupakan bagian integral dari kegiatan pendidikan, penelitian dan pengabdian kepada masyarakat (tri dharma perguruan tinggi) serta berfungsi sebagai pusat sumber pengetahuan seluruh civitas akademika di perguruan tinggi Islam. 
Di sisi lain, revitalisasi peran dan profesionalisme pustakawan merupakan masalah kepustakawanan Islam di Indonesia, selain masalah pendanaan dan pengukuran kualitas yang terstandar. ${ }^{212223}$ Masalah klasik yang dapat kita temui di perguruan tinggi Islam adalah belum terealisasinya jargon-jargon seperti “jantungnya perguruan tinggi", terutama karena peran dan posisi perpustakaan di dunia akademik masih lebih berupa "pendukung", jauh dari kesan penentu. Ini tidak berarti bahwa perpustakaan diabaikan sama sekali, ada banyak perguruan tinggi Islam besar, baik negeri maupun swasta, yang amat serius mengembangkan sarana dan prasarana perpustakaan mereka. Digitalisasi dan peningkatan akses ke internet, khususnya ke jurnal-jurnal eletronik, menjadi salah satu bukti keseriusan itu.

Namun tentu saja peran perpustakaan tidak dapat hanya ditunjukkan dalam bentuk penyediaan sarana fisik. Salah satu aspek penting dalam menegaskan nilai penting dari perpustakaan adalah bukti-bukti yang teranalisis tentang sumbangan jasa maupun koleksinya bagi kemajuan penelitian dan pengajaran di lembaga induk. Saat ini sebenarnya sudah tersedia Standar Nasional Indonesia Perpustakaan Perguruan Tinggi (SNI 7330:2009) dan proses akreditasi oleh Perpustakaan Nasional Republik Indonesia maupun Badan Akreditasi Nasional Perguruan Tinggi sebagai sarana untuk menjamin mutu dari perpustakaan.

Di sisi lain, berkaitan dengan gerakan open access dan pengembangan institusional repositori, masih banyak dosen/ peneliti yang belum memahami manfaat serta peluang dari kebebasan open access dan repositori institusional. Pada saat yang sama pula, masih banyak pustakawan dan pengelola perpustakaan

${ }^{21}$ A.R. Siregar, Perluasan peran perpustakaan perguruan tinggi. Pustaha; jurnal studi perpustakaan dan informasi, 4 (1), 2008, h. 7-11. (http://repository. usu.ac.id/bitstream/123456789/16086/1/pus-jun2008-(1).pdf

${ }^{22}$ Abdul Rahman Saleh, Peran perpustakaan di perguruan tinggi belum optimal. Mengapa?. 2010. Rahman Blog. (http://rahman.staff.ipb. ac.id/2010/12/23/peran-perpustakaan-di-perguruan-tinggi-belum-optimalmengapa/

${ }^{23}$ P. Suparmo, Menggagas kualitas perpustakaan perguruan tinggi. Visi Pustaka, 14 (3), 51-59. 2012. 
tinggi Islam yang belum terlalu tahu tentang open access, misalnya jika dikaitkan dengan langganan jurnal elektronik dan skemaskema kontrak yang mereka lakukan dengan para vendor. Program-program literasi informasi yang melibatkan dosen dalam konteks memanfaatkan jurnal elektronik dan fenomena open access dapat membantu sebuah perguruan tinggi membentuk komunitas praktis. Keterlibatan pihak-pihak yang selama ini menangani terbitan perguruan tinggi juga akan menciptakan integrasi yang kondusif bagi peningkatan kapasitas riset suatu perguruan tinggi.

Salah satu persoalan yang dihadapi perguruan tinggi dimana mana termasuk perguruan tinggi Islam khususnya dalam kaitannya dengan jurnal elektronik adalah perubahan dalam model komunikasi ilmiah antar ilmuwan, dan hubungan antara ilmuwan dengan jurnal elektronik. Secara abritrer para penyelenggara jurnal elektronik memang telah berhasil menciptakan model kerjasama antara diri mereka dengan perpustakaan, namun model ini semata-mata berorientasi bisnis. Belumlah terlalu jelas, bagaimana model ini dapat dijustifikasi dengan peningkatan kapasitas riset di perguruan tinggi yang melanggannya. Apalagi di negaranegara berkembang seperti Indonesia yang para ilmuwannya masih lebih banyak menjadi konsumen artikel-artikel ilmiah yang ditulis ilmuwan luar negeri. Sebab itulah, menjadi amat relevan dan penting jika para pustakawan ikut menggerakkan dosen/ peneliti mengaktifkan sarana repositori institusional sebagai cara memaparkan diri mereka ke dunia luar.

Di era 4.0 ini berkat kemajuan teknologi informasi dan jaringan, kesulitan berbagi dokumen dapat diatasi dan perguruan tinggi Islam pada saat ini sudah mulai membangun sistem informasi penelitian berbasis web. Akses secara online mempermudah proses dan manajemen penelitian oleh civitas akademika, selain juga memungkinkan efisiensi dalam pemantauan dan evaluasi kinerja pihak-pihak yang terlibat. Selain mempermudah manajemen penelitian, beberapa perguruan tinggi sudah menyadari pentingnya integrasi sistem informasi ini dengan sistem perpustakaan. Sebagai 
contoh Universitas Sumatera Utara yang mempunyai Pusat Sistem Informasi yang berada satu atap dengan perpustakaan di bawah unit Perpustakaan dan Sistem Informasi. Penulis belum menemukan data apakah perguruan tinggi Islam sudah ada yang menerapkan sistem ini.

Jika integrasi antar berbagai sistem informasi di perguruan tinggi sudah ada, maka menurut Pendit, perpustakaan dapat berinisiatif mengembangkan apa yang disebut digital asset management (DAM) khusus penelitian. ${ }^{24}$ Manajemen seperti ini akan membantu perpustakaan mengelola hasil-hasil penelitian sebagai aset, alih-alih sebagai semata-mata koleksi. Pengelolaan yang seksama terhadap hasil-hasil penelitian sebagai aset perguruan tinggi pada akhirnya dapat membantu perpustakaan dapat membuktikan peran mereka dalam meningkatkan kinerja maupun kualitas penelitian lembaga induk mereka.

Ratnaningsih (2008) dalam pidato pengukuhan pustakawan utamanya menyatakan bahwa memang investasi terhadap suatu perpustakaan baru terasa apabila perguruan tinggi tersebut telah mampu menghasilkan lulusan yang mempunyai reputasi baik nasional, regional maupun tingkat dunia di bidang studi masingmasing. Hal tersebut bisa terjadi apabila ketersediaan fasilitas dan ketercukupan informasi yang berkelas dunia tersedia dan bisa diperoleh serta dimanfaatkan oleh para sevitas akademikanya. Hal ini tentunya menjadi tantangan tersendiri bagi perpustakaan perguruan tinggi Islam di era 4.0 seperti sekarang ini.

Memiliki akses e-books harus lebih besar dari 10.000 judul dirasa mungkin tidak terlalu berat karena akhir-akhir ini banyak situs-situs website yang menyediakan e-book yang dapat di download dengan 'free' untuk kepentingan pemustaka. Tinggal bagaimana perpustakaan yang belum mampu menyediakan e-book sejumlah itu harus pro aktif dan kreatif. Pengadaan buku minimal

${ }^{24}$ Putu Laxman Pendit, Peringkat universitas, budaya epistemik dan tantangannya bagi perpustakaan perguruan tinggi. Makalah Seminar Nasional Pengembangan Perpustakaan Akademik, Rabu 12 Agustus 2015. Ciputat: UIN Syarif Hidayatullah. 
100.000 eksemplar/ tahun. Pada kegiatan inilah perpustakaan memerlukan anggaran yang lumayan besar. Katakan bila ratarata buku import per eks. seharga Rp. 1 juta, maka sedikitnya diperlukan Rp. 100.000.000.000,- untuk pengadaan buku pertahun, namun lain lagi kalau kebijakan untuk pengadaan buku lokal saja, bisa jadi dapat terpenuhi, karena harga buku lokal tidak semahal buku import.

Apa yang disampaikan oleh Ratnaningsih di atas merupakan gambaran ketika sedang booming-nya masalah world class university yang terjadi beberapa tahun yang lalu. Ketika itu semua perpustakaan perguruan tinggi berlomba-lomba untuk memenuhi indikator parameter world class university. Akan tetapi kini kita telah memasuki era 4.0 yaitu era revolusi teknologi informasi, maka perpustakaan perguruan tinggi Islam harus menyikapi secara cepat dan tepat sehingga perpustakaan tidak tergerus oleh zaman dan tidak ketinggalan oleh perpustakaan perguruan tinggi di bawah naungan Kemenristekdikti.

Direktorat pendidikan tinggi Islam dalam 3 (tiga) tahun terakhir yaitu sejak 2015, 2016 dan 2017 telah melakukan terobosan dalam rangka meningkatkan kualifikasi keilmuan dan kompetensi serta pengalaman bagi para pustakawan perguruan tinggi Islam yaitu melalui kegiatan DELSMA (Development of Library System Management). Kegiatan ini merupakan kegiatan yang sangat positif dalam rangka menambah pengalaman dan pengetahun pustakawan ke luar negeri. Tahun 2015 dan 2016, para pustakawan yang lolos seleksi dikirim ke Negara Australia. Disana para pustakawan dari berbagai perpustakaan perguruan tinggi Islam yang ada di tanah air belajar mengenai bagaimana pengelolaan dan sistem perpustakaan yang ada di Negara Australia. Begitupun tahun 2017, pada tahun tersebut penulis menjadi salah satu pesertanya setelah mengikuti rangkaian kegiatan seleksi mulai dari seleksi administrasi, test tertulis dan test bahasa Inggris (baik kemampuan menulis, menterjemahkan, mendengarkan, memahami suatu percakapan berbahasa Inggris, dan kemampuan untuk berdialog dalam bahasa 
Inggris). Pada Tahun 2017, tujuan negera dari kegiatan DELSMA adalah Negara Jerman. Banyak hal-hal positif dan pengalaman yang berharga yang diperoleh dari kegiatan tersebut. Kegiatankegiatan positif sepertinya harus selalu dihidupkan di lingkungan perguruan tinggi Islam sehingga sumber daya manusia (SDM) kepustakawanan Islam mampu bersaing baik dalam skala nasional maupun internasional.

Untuk itu, perpustakaan perguruan tinggi Islam tidak boleh berhenti berinovasi, ke depan, bisa menjadi tempat untuk menemukan pengalaman yang lebih kaya bagi pemustakanya. Dengan menjadi perpustakaan perguruan tinggi Islam inovatif, perpustakaan akan selalu hidup, memberikan pengalaman baru, dan menghasilkan nilai tambah bagi orang-orang di sekitarnya dan menjadi paru-paru pengetahuan di dunia pendidikan. Demikian juga lembaga yang menaunginya baik itu perguruan tinggi Islam dimana perpustakaan itu berada maupun Direktorat Pendidikan Tinggi Keagamaan Islam (Diktis Kemenag RI) hendaknya selalu mensupprot dunia kepustakawanan Islam untuk selalu berinovasi sesuai dengan perkembangan zaman. Dukungan moral spritual dan material sangat menentukan keberlangsungan dunia kepustakawan Islam di Indonesia.

\section{Simpulan}

Perpustakaan perguruan tinggi Islam menghadapi era 4.0 tentunya harus berbenah dalam rangka memperkuat peran dan fungsinya dalam menunjang kegiatan akademik perguruan tinggi Islam. Pembenahan terhadap segala problematika harus dilakukan agar dapat memberikan pelayanan terbaik terhadap pemustaka sehingga pemustaka merasa puas. Segala kekurangan harus dibenahi. Selain pembenahan secara intern perpustakaan itu sendiri, juga harus mendapat dukungan dari luar salah satunya adalah Direktorat Jenderal Pendidikan Islam Kementerian Agama Republik Indonesia. Dalam hal ini pihak Dirjen Pendis telah membuktikan keseriusannya dalam memberikan perhatian 
pada perpustakaan dan kepustakawanan yaitu melalui kegiatan Development of Library System Management (DELSMA), dan kegiatan lainnya yang menunjang pengembangan kualitas dan kompetensi pustakawan di Kementerian Agama RI. Kegiatankegiatan yang positif dan konstruktif seperti DELSMA ini kiranya perlu ditingkatkan sehingga SDM kepustakawanan Islam bisa menjadi salah satu icon dan motor penggerak kemajuan dunia kepustakawanan di era 4.0 seperti sekarang ini. 


\section{DAFTAR PUSTAKA}

Azmar, NJ. (2018). Masa depan perpustakaan seiring perkembangan revolusi industry 4.0 : mengevaluasi peranan pustakawan. Jurnal Iqra' 10(01): 35-37.

Association of College and Research Libraries. 2012. "Connect, Collaborate, and Communicate: A Report from the Value of Academic Libraries Summits. Prepared by Karen Brown and Kara J. Malenfant. Chicago: Association of College and Research Libraries. (www.acrl.ala.org/value, diakses 30 januari 2019).

Association of College and Research Libraries. 2010. Value of Academic Libraries: A Comprehensive Research Review and Report. Research by Megan Oakleaf. Chicago: Association of College and Research Libraries. (http://www.ala.org/acrl/ sites/ala.org.acrl/files/content/issues/value/val_report.pdf, diakses 30 Januari 2019).

Bradley M, Hemminger, B.M., Lu, D., Vaughan, K.T., dan Adams, S.J. (2007). "Information Seeking behavior of academic scientists". Journal of the American Society for Information Science and Technology, 58 (14), 2205-2225.

Fatmawati, Endang. (2018). Disruptif diri pustakawan dalam menghadapi era revolusi industri 4.0. Jurnal Iqra' 12 (01) Mei 2018: 1-13.

Haines, L.1., Light, J., \& O’Malley, D. (2010). “Information-seeking behavior of basic science researchs: implications for library services." Journal for Medical Library Association, 98 (1), 73-81.

Hepworth, M. \& Duvigneau, S. (2012). Building Research Capacity: Enabling Critical Thinking Through Information Literacy in Higher Education in Africa, Brighton, UK: the Institute of Development Studies. (http://opendocs. 
ids.ac.uk/opendocs/bitstream/handle/123456789/2301/ BuildingResearchCapacityR1.pdf).

Indonesia. (2003). Undang-Undang No. 20 Tahun 2003 tentang Sistem Pendidikan Nasional Pasal 55. Jakarta: Departemen Pendidikan Nasional.

Indonesia. (2007). Undang-undang Nomor 43 tahun 2007 tentang perpustakaan. Jakarta: Perpustakaan Nasional RI.

Jingfeng, X. (2011). "An anthropological emic-etic perspective on open access practices. Journal of Documentation, 67 (1), 75-94. Doi: 10.1108/00220411111105461.

Muntashir. (2012). "Analisis webometrics pada perpustakaan perguruan tinggi negeri di Indonesia”. Visi Pustaka, 14 (2), 39-49.

Majidah. (2018). Perubahan kultur akses informasi pustakawan dan pemustaka dalam revolusi industry 4.0 , dalam proceeding open society Conference 2018, 35-46. Diunduh dari http:// repository.ut.ac.id/7953/1/ocs-2018-3.pdf.

Nashihuddin, W., Suryono, F. (2018). Tinjauan terhadap Kesiapan Pustakawan dalam Menghadapi Distrupsi Profesi di Era Library 4.0: Sebuah Literatur Review. Khizanah al- Hikmah : Jurnal Ilmu Perpustakaan, Informasi, dan Kearsipan. 6(2), 86-97. Diunduh dari http://journal.uin-alauddin.ac.id/ index.php/khizanah-al-hikmah/article/view/5922.

Noh, Younghee. (2015). Imagining Library 4.0: Creating a Modelfor Future Libraries. The Journal of Academic Librarianship,41(6),789-795. Diunduh dari http://dx.doi. org/10.1016/j.acalib.2015.08,020

Perpustakaan Nasional. (2015). Rencana Strategis Perpustakaan Nasional RI 2015-2019, Bab III tentang arah dan kebijakan, strategi, kerangka regulasi, dan kerangka kelembagaan. Jakarta: Perpustakaan Nasional RI.

Pendit, Putu Laxman. (2015). Peringkat universitas, budaya epistemik dan tantangannya bagi perpustakaan perguruan 
tinggi. Makalah Seminar Nasional Pengembangan Perpustakaan Akademik, Rabu 12 Agustus 2015. Ciputat: UIN Syarif Hidayatullah.

Ristiyono, M.Pandu. (2018). Peran Pustakawan Pendidikan Jarak Jauh di era Disrupsi; Studi kasus di Perpustakaan Universitas Terbuka. Makalah disampaikan pada Seminar Nasional Kearsipan dan Perpustakaan di Institut Pertanian Bogor (IPB) Gedung andi Hakim Nasution 10 - 11 juli 2018. Diunduh dari http://repository.ut.ac.id/7785/1/PANDUOK-IPB--full\%20papaer\%20IPB-buat\%20Repository.pdf.

Rodin, Rhoni. (2018). Optimalisasi layanan digital berbasis android untuk memperkuat inovasi dan kreativitas perpustakaan iain curup. Dalam Prosiding SNIPer Lampung 5-7 November 2018, hal. 109. Diunduh dari http://eprints.umpo. ac.id/4692/1/e-Prosiding-SNIPer-2018\%20cover.pdf.

Sulistyo Basuki. (1991), Pengantar Ilmu Perpustakaan. Jakarta: Gramedia Pustaka.

Suparmo, P. (2012). "Menggagas kualitas perpustakaan perguruan tinggi”. Visi Pustaka, 14 (3), 51-59.

Siregar, A.R. (2008). "Perluasan peran perpustakaan perguruan tinggi”. Pustaha; jurnal studi perpustakaan dan informasi, 4 (1), 7-11. (http://repository.usu.ac.id/ bitstream/123456789/16086/1/pus-jun2008-(1).pdf

Xuemei, G. (2010). "Information-seeking behavior in the digital age: a multidisciplinary study of academic researchs". College \& Research Libraries, 71 (5), 435-455. (http://crl. acrl.org/content/71/5/435.full.pdf+html.

Saleh, A.R. 2010. "Peran perpustakaan di perguruan tinggi belum optimal. Mengapa?". Rahman Blog. (http://rahman.staff. ipb.ac.id/2010/12/23/peran-perpustakaan-di-perguruantinggi-belum-optimal-mengapa/ 